\title{
CASC4 Gene
}

National Cancer Institute

\section{Source}

National Cancer Institute. CASC4 Gene. NCI Thesaurus. Code C131614.

This gene may play a role in Golgi apparatus activity and tumor growth. 